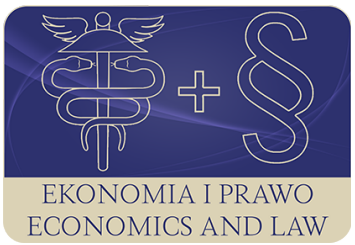

EKONOMIA I PRAWO. ECONOMICS AND LAW

Volume 18, Issue 4, December 2019

p-ISSN 1898-2255, e-ISSN 2392-1625

www.economicsandlaw.pl

ORIGINAL ARTICLE

received 30.03.2019; revised 12.12.2019; accepted 31.12.2019

Citation: Twarowska, K. (2019). Reforms of China's exchange rate regime and the renminbi internationalization. Ekonomia i Prawo. Economics and Law, 18(4): 531-556.

doi:10.12775/EiP.2019.035.

\title{
Reforms of China's exchange rate regime and the renminbi internationalization
}

\author{
KATARZYNA TWAROWSKA \\ Maria Curie-Skłodowska University in Lublin, Faculty of Economics, World Economy and European \\ Integration Chair, pl. M. Curie-Skłodowskiej 5, 20-031 Lublin, Poland \\ 曰.twarowska@umcs.pl \\ Dorcid.org/0000-0002-2508-0153
}

\begin{abstract}
Motivation: After four decades of very successful reforms, China has become one of the largest economies in the world. An important area of these reforms is the exchange rate system and monetary policy, which over the years has complied with economic objectives, in particular the promotion of economic growth by improving export competitiveness. The progressive liberalisation of the Chinese economy and its ever closer integration into the world economy require this policy to be adapted to changing circumstances. Aim: The aim of the article is to analyze China's exchange rate policy from the perspective of the dilemma of choosing between using this policy to support export competitiveness and striving to internationalise the renminbi. Moreover, the author assesses the consequences of this policy for China's economy and for the world economy. The study includes theoretical research (analysis of the literature and research reports) and empirical research

(analysis of statistical data) using a descriptive analysis.

Results: For many years China's exchange rate policy has been focused on supporting economic growth by improving export competitiveness, resulting in both increasing internal imbalances and difficulties in stabilising inflation, as well as the accumulation of global

payments imbalances. Since 2005 China has made its currency more flexible, so that the underestimation of the renminbi's exchange rate has decreased. In recent years, China has intensified its efforts to support the internationalisation of the renminbi. However, the renminbi is not yet in rivalry with the US dollar as the dominant international currency, although the Chinese currency's share as an international currency is increasing,

which should have a positive impact on the stability of global financial relations.
\end{abstract}




\section{Keywords: exchange rate policy; export-led growth strategy; trade competitiveness; global imbalances; renminbi internationalization \\ JEL: F31; F32; F40; N25; O24}

\section{Introduction}

The importance of China's exchange rate policy is related to the growing role of the Middle Kingdom in the world economy and the influence exerted on economies of other countries, such as by contributing to the creation of global imbalances. The fixed exchange rate system, which has been maintained for years, has favoured the development of Chinese trade not only by eliminating the exchange rate risk, but in particular by maintaining the undervalued renminbi rate through significant, systemic and one-way currency market interventions of the People's Bank of China. The exchange rate policy was used as an instrument to implement the export-led growth strategy.

The Chinese economy has developed particularly well since 2001, with China's accession to the World Trade Organisation (December 2001), resulting in the removal of barriers to the access of Chinese goods to the markets of other Member States. Thanks to this, since 2001 China's exports have been growing very intensively, leading to huge current account surpluses and an unprecedented accumulation of foreign exchange reserves. The costs of maintaining a fixed exchange rate, as well as the growing economic openness and willingness to take advantage of having an international currency, have encouraged the Chinese authorities in recent years to support the internationalisation of the renminbi.

The significance of the China's economy and policy has encouraged the author to undertake research, the aim of which is to analyze China's exchange rate policy from the perspective of the dilemma of choosing between using this policy to support export competitiveness and striving to internationalise the renminbi. Moreover, the author assesses the consequences of this policy for China's economy and for the world economy.

\section{Theoretical framework and literature review}

For decades, the exchange rate has been at the heart of economic policy debates in developing countries. In many countries, nominal exchange rate has been used as a tool to reduce inflation, in other countries, including China and Latin America, to influence exports. Scientists and politicians are discussing the advantages of alternative exchange rate regimes for developing economies. Using theories based on credibility, the authors argue that developing economies and emerging markets should adopt fixed exchange rate regimes, mainly the currency board system or dollarization (Edwards, 2006, p. 1). One of the reasons for the adoption of a fixed exchange rate system was that emerging economies experienced fear of floating (Calvo, 1999; Calvo \& Reinhart, 2002, pp. 379-408). 
Managing the exchange rate gives an opportunity to influence the export competitiveness. The effectiveness of different exchange rate systems in promoting competitiveness in international trade and their impact on macroeconomic stability have been discussed by Wickham (1985), Sachs (1996), Frenkel (1996) and others as part of an ongoing scholarly debate (Drabek \& Brada, 1998).

For years, an active exchange rate policy has been an element of China's export-led growth strategy. China's authorities used the devaluation of the renminbi as an instrument for supporting their exports. In the early 2000s, when China was running huge trade surpluses and amassing huge foreign exchange reserves, renminbi undervaluation and misalignment were popular topic. Empirical studies on renminbi misalignment of that period include Cheung et al. (2007), Cline (2015), Frankel (2006), Funke \& Rahn (2005), Korhonen \& Ritola (2011) and Schnatz (2011) (compare Cheung et al., 2018, p. 165) (see table $1)$.

On the other hand, an important advantage of variable exchange rates is the possibility to conduct an autonomous monetary policy, which is particularly important when liberalising capital flows. Moreover, the change of exchange rate regime to a floating exchange rate and financial market liberalization is a necessary condition for currency internationalization (Chinn \& Frankel, 2007, pp. 283-322) and, as a result, the benefits of having an international currency, such as obtaining income from the issue of an international currency, the so-called seigniorage, the possibility of borrowing abroad in own currency, lower profitability of bonds issued by the government, which reduces the costs of servicing foreign debt and achieving much higher benefits from foreign investments (direct and portfolio) compared to the costs of servicing foreign debt (exorbitant priviledge) (Eichengreen, 2011).

Since the early 2000s, and in particular since the financial and economic crisis of 2008-2009, China has taken steps to support the internationalisation of the renminbi in order to obtain benefits of having an international currency (Cheung et al., 2018, p. 165). The reasons for the internationalisation of the renminbi, as well as the effects of this process on both the Chinese and the world economy, are the subject of the work of the following authors: Chen \& Cheung (2011, pp. 1-18), Cheung et al. (2011, pp. 1-17), Eichengreen \& Kawai (2015), Frankel (2012, pp. 329-365) and Prasad (2016, pp. 207-256). China's efforts to promote overseas use of the renminbi have been welcomed with great enthusiasm by other countries, which see this as an opportunity to alleviate global payments imbalances.

\section{Methods}

In order to achieve the main objective of the article, which is to assess China's exchange rate policy, the author carried out theoretical considerations on the impact of the exchange rate on the national economy and the benefits of having an international currency, as well as empirical research. Theoretical 
analyses are based on the rich literature. Moreover, descriptive analysis was used in empirical studies. The following indicators were used to assess the results of exchange rate policy: official exchange rate, real effective exchange rate, GDP growth, current account balance, index of global payment imbalances, foreign exchange reserves, broad money, inflation CPI, currencies' shares in international payments, currency distribution of OTC foreign exchange turnover, currency composition of official foreign reserves. The period of detailed analysis is 1990-2018, with the analysis of selected indicators extending back to earlier years. The data used in the article were obtained from the following databases: World Bank (2018), International Monetary Found (IMF, 2018), COFER (2018), UNCTAD (2018), SWIFT (2018), Bank of International Settlements (BIS, 2016).

The author formulated the following research hypothesis: The main objective of China's exchange rate policy was to improve export competitiveness, but China's growing economic openness contributes to making the renminbi exchange rate more flexible and to making efforts to support the internationalisation of the Chinese currency.

\section{Results}

\subsection{Evolution of China's exchange rate policy}

China's monetary policy has significantly changed since the beginning of the market transformation in 1978. Between 1979 and 1993, the renminbi was an inconvertible currency and there was a dual exchange rate arrangements ${ }^{1}$, and the value of exchange rates was established arbitrarily. There were foreign exchange restrictions on current account and capital account transactions. When the systemic transformation began, all currency exchange transactions were monopolized by the Bank of China. As part of the liberalisation of the economy, it was also possible to exchange currencies through other domestic banks and branches of foreign banks, which initially operated only in special economic zones, were able to make transactions in foreign currencies.

In 1985 the dual rate system was replaced with an unified exchange rate and between 1986 and 1994 a regime of managed float with a narrow band was in force (Cardoso \& Duarte, 2017, p. 872). In 1994 China decided to index the value of its currency to the US dollar and renminbi was maintained at a relatively stable level over the following years. The exchange rate was set at 8.7 USD/RMB, which was a significant nominal devaluation, as the renminbi exchange rate was 5.8 USD/RMB before the devaluation (Cheung et al., 2016, p. 2). Such a large scale of devaluation can be explained by very high inflation in China in 1993-1995, which caused the scale of real devaluation to be small.

1 The official exchange rates were two: one related to non-commercial transactions and the other related to commercial transactions. 
The renminbi was allowed to trade within a defined band around its daily official fixing announced by the People's Bank of China. Initially, the daily trading band against the US dollar was set at 0.3\% around fixing. Furthermore, in April 1994 the China Foreign Exchange Trade System (CFETS) was established to organize and support interbank renminbi trading (Cheung et al., 2016, p. 3). By 1996, the possibility for current account transactions was also introduced, making the renminbi a convertible currency according to the standard set out in Article VIII of the IMF Statute. However, with the outbreak of the Asian crisis in 1997, the Chinese monetary authorities decided to fix the exchange rate against the dollar and the official exchange rate was revalued to $8.28 \mathrm{USD} / \mathrm{RMB}$. It was maintained at that level for the next 7 years - until July 2005 (chart 1).

Since the late 1990s, charges from the US that the renminbi exchange rate is underestimated have intensified, and in 2005 the US Congress attempted to apply customs protectionism against Chinese imports on the basis of accusations that exchange rate policy was being used as an instrument to support exports. In the face of external pressure, China has decided to reform its exchange rate policy. On 21st July 2005 the People's Bank of China revalued the renminbi against the dollar from 8.28 USD/RMB to 8.11 and announced an introduction of the managed floating exchange rate regime based on market demand and supply, and with reference to a basket of currencies (Cardoso \& Duarte, 2017, pp. 870-893). However, the structure of the basket was not precisely defined. The People's Bank of China specified the currency composition of the basket, but did not specify the weights of the particular currencies making up the basket. The basket consisted of two groups of currencies: the main currencies (US dollar, euro, yen and South Korean won) and the minor currencies (Singapore dollar, Malaysian ringgit, Australian dollar, Canadian dollar, ruble and Thai baht) (Funke \& Gronwald, 2008, p. 1583). The choice of currencies and their weights depended not only on the pattern of China's trade but also on the sources of its foreign direct investment and the currency composition of its reserves. However, the renminbi has remained quite strongly linked to the US dollar (Cheung et al., 2016, p. 3). The scale of the nominal appreciation of the renminbi against the dollar was 3\% in 2005 and 2006, and then increased to 7\% in 2007 and 2008. The nominal exchange rate of the renminbi fell from RMB 8.11 for USD 1 in July 2005 to RMB 6.83 for USD 1 in July 2008. China has gradually widened the trading band around the daily US dollar fixing from initial $\pm 0.3 \%$ to $\pm 0.5 \%$ on May 21,2007 .

During the crisis, when demand for exports fell, China sought to limit the appreciation of the renminbi in order to support exports. Therefore from July 2008 to June 2010 China resorted to a stable exchange rate policy, that maintained the value of the renminbi quite close to the level of RMB 6.83 against one US dollar. Exchange rate policy became part of the stimulus package. After the crisis symptoms have disappeared and exports have returned to a growth path, China announced on June 19, 2010 further reforms to its exchange rate formation mechanism based on measures taken in 2005. Peoples Bank of China 
repeated the 2005 declared policy of managing the RMB against a basket of currencies with an acceptable fluctuation band around the parity of $\pm 0.5 \%$ (Cheung et al., 2016, p. 3). A more flexible exchange rate policy resulted in an appreciation of the renminbi against the dollar and this trend continued until mid-2014. China has gradually widened the trading band from $\pm 0.5 \%$ to $\pm 1 \%$ on April 16, 2012 and $\pm 2 \%$ on March 17, 2014. Furthermore, the renminbi has had an offshore and onshore $(\mathrm{CNY})$ exchange rate $(\mathrm{CNH})$ since 8 October 2010. The offshore rate is subject to less intervention, and, thus, better reflects market information (Cheung et al., 2018, p. 166).

On 11 August 2015, China changed its procedure for setting the official central parity of the renminbi against the US dollar. The central bank claimed that the new formation mechanism would give market forces a greater role in setting the daily official rate, also known as the fixing rate, by referring to the previous day's closing rate of the renminbi, market demand and supply, and the valuation of other major currencies (Cheung et al., 2018, pp. 164-165) ${ }^{2}$. This change was not well received and renminbi depreciated by $4.4 \%$ over the first 3 trading days under the new fixing procedure(Cheung et al., 2018, p. 164). The China Foreign Exchange Trade System (CFETS) announced a few days later the renminbi index with its component currencies and their weights, which is called CFETS RMB index ${ }^{3}$.

Repeated reassurances and administrative measures, including reported interventions in the onshore and offshore markets, had no impact on market volatility or restoring confidence. It was quite common on the market to believe, that new fixing procedure was just a thinly veiled devaluation to revive the weak economy (Cheung et al., 2018, p. 165).

Despite the negative market reception, the IMF Executive Board in November 2015 reiterated its endorsement of China's endeavors at reforming its exchange rate policy by making the renminbi the fifth currency of the Special Drawing Rights (SDR) currency basket along with the US dollar, the euro, the Japanese yen and the pound sterling (Harrison \& Xiao, 2018, p. 47). The Chinese currency was judged to meet the criteria needed for inclusion, including the fact that it is issued by a country which has had a large export market in the past five years and that it is 'freely usable'. A 'freely usable' currency is defined as a currency that the IMF determines as being widely used to make payments for international transactions and which is widely traded in the principal exchange markets (ECB, 2017, p. 12). The new SDR basket has come

${ }^{2}$ CFETS was authorized by the People Bank of China to calculate and publish the central parity of the renminbi. Before August 11, 2015, the fixing was based on a trimmed weighted average of prices from designated liquidity providers, and the weights were set discretionally.

${ }^{3}$ Since November 2015 in the CFETS index 13 currencies were included and 24 currencies since January 2017. The de facto exchange rate arrangement has been reclassified twice: (1) retroactively to crawl-like from other managed, effective from 11 November 2015; and (2) to stabilised from crawl-like, effective from 24 August 2016. 
into use ten months later on October 1, 2016. The inclusion of the renminbi in the SDR basket should promote the internationalisation of China's currency, but this was not the case because China, in the face of capital outflow and weakening economic growth introduced in 2016 a capital controls, which reduced the use of renminbi as a currency for global international payments. Therefore, the Chinese currency is still not fully convertible, not least after the temporary reintroduction of capital controls in China in 2016 which, since then, have been gradually lifted (ECB, 2018, pp. 9-11). Chart 1 shows the evolution of the official exchange rate over the period between 1980 and 2017 and chart 2 shows the real effective exchange rate since 1990 to September 2018.

\subsection{China's exchange rate policy and export-led growth strategy}

The role of exchange rate policy in the economy depends on the degree of its openness. In a closed economy it does not play a significant role, whereas in an open economy it is one of the key components of macroeconomic policy. As China is a country with a high share of foreign trade in GDP, which amounted to $63.6 \%$ in $2006^{4}$, the exchange rate plays a special role in its economy. The renminbi exchange rate system is considered to be one of the key factors behind China's accelerated economic growth and rapid advancement in the global economy.

In the early stage of the transformation lasting until the mid-1990s, the proimport model dominated. The development of the economy required the delivery of goods from abroad and the demand for imports was high, which resulted in a negative balance of trade (chart 3). A significant share of Chinese imports had capital goods, which increased China's export potential. During this period the Chinese currency was relatively strong, which also did not improve the price competitiveness of Chinese exports.

Since the mid-1990s, the importance of exports has been growing in the economic growth of China, which pursued the export-led growth strategy. China was becoming an increasingly open economy, and trade liberalisation accelerated especially after China joined the World Trade Organization in 2001, resulting in a rapid increase in exports in the early 2000s (Pasierbiak, 2017, p. 54). China's exchange rate policy was also conducive to its export-led growth strategy. The devaluation of the renminbi in 1994 from 5.8 USD/RMB to 8.7 USD/RMB improved the competitiveness of Chinese exports, which resulted in a growing surplus in the current account (CA) (chart 3 and 4). Rapid export growth and surpluses on CA contributed to a high GDP growth. Many studies concerning that period indicated that the renminbi exchange rate was significantly undervaluated. Estimates indicated a deviation of the nominal exchange rate from the equilibrium exchange rate of 20-30\% (Cardoso \& Duarte, 2017,

${ }^{4}$ In subsequent years, the share of trade in GDP in China (the economic openness index calculated as the ratio of total exports and imports of goods and services to GDP) decreased to $37 \%$ in 2016 and $38.7 \%$ in 2017. 
p. 875). Pressure from other countries, in particular the US, led China to make the exchange rate system more flexible in 2005, resulting in an appreciation of the renminbi. The appreciation trend continued in the period of July 2005July 2008 (Cheung et al., 2016), but the renminbi was still underestimated, which resulted in a further increase in the surplus on CA.

The global financial and economic crisis has led to a decline in demand for Chinese exports and, as a result, a slowdown in GDP growth, which has highlighted the significant dependence of Chinese economic growth on foreign demand for imports from China. In order to support exports, China has once again fixed its currency against the dollar (from July 2008 to June 2010). However, China's trade surplus declined during the crisis.

The problems related to export-led growth strategy, which materialised during the crisis, encouraged China to change its development strategy. Since then, more and more emphasis has been placed on stimulating domestic demand ( $\mathrm{Su}$ et al., 2018, p. 2). In addition, the depreciation of the US dollar during the crisis has meant that China has suffered a significant impairment of its foreign exchange reserves, of which US dollar assets account for a significant share. In these circumstances, China has begun to see the opportunities that may arise from the internationalisation of its currency.

Maintaining the undervalued renminbi required the Chinese monetary authorities to intervene in the foreign exchange market, which resulted in a high rate of accumulation of foreign exchange reserves (chart 5). These reserves are maintained mainly in US assets, in particular in treasury bonds issued by the US government.

The reasons for the accumulation of foreign exchange reserves in China include in particular:

- the will to prevent a currency crisis: there is no exchange rate risk under fixed exchange rate regimes that could limit the inflow of short-term speculative capital; in the case of China, the risk of a sudden flow of hot money and its destabilising effect on the exchange rate is one of the reasons for maintaining huge foreign exchange reserves that can be used to defend the exchange rate in the face of a sudden capital outflow;

- the possibility of investing reserves (purchase of almost risk-free US government debt securities);

- interventions in the foreign exchange market in order to maintain the underestimated renminbi (purchase of foreign currencies for national currency).

These factors have led to China having the largest foreign exchange reserves in the world since 2006 (table 2). Maintaining a high level of foreign exchange reserves is supposed to ensure financial security, but too high level of foreign exchange reserves is a source of costs and requires an effective investment strategy. China invests especially in low-risk and highly liquid assets. Investment in US dollar-denominated assets is particularly high, especially long-term government bonds. According to data provided by the U.S. Department of the Treasury (2018), China is the largest holder of U.S. Treasury bonds. 
China's exchange rate policy has been a source of significant costs for the Chinese economy and has jeopardised financial stability. In order to maintain the exchange rate at the desired level, the monetary authorities of China intervene in the exchange market by buying foreign currencies and increasing the supply of the renminbi. To prevent an excessive increase in money supply as a result of currency market interventions, the central bank of China sterilises these interventions through the use of open market operations in the form of the issuance of short-term money bills. However, these interventions are not fully sterilised, and as a result the amount of money in the economy is increasing, which is accompanied by rising inflation (Zhang, 2012, pp. 41-58). In 1994, when China reformed its exchange rate system and devalued the renminbi, the ratio of the money supply (broad money ${ }^{5}$ ) to GDP was $96.5 \%$, which was close to the average rate in the world economy, which amounted to $93.2 \%$. In the following years, the relationship grew in China to $157.5 \%$ in 2006, then slightly decreased after the renminbi revaluation in mid-2005 and under the conditions of the managed floating exchange rate regime. However, after China returned to more stringent exchange rate control during the crisis (since mid-2008) and in conditions of increased frequency of interventions on the currency market in order to maintain the underestimated renminbi and promote export competitiveness, the money supply started to grow again, reaching $175 \%$ of GDP in 2009 (chart 6). After returning to a more flexible exchange rate policy in mid-2010, the money supply declined, but it was a short-term change, as since 2012 it has risen again to 208.5\% of GDP in 2016 and 202.6\% in 2017, while the average rate in the world economy was $125 \%$ of GDP.

An increase in the money supply results in inflationary pressures which the Chinese economy has been suffering from (chart 7). In particular, high inflation followed the devaluation of the renminbi exchange rate in 1994, when consumer prices rose by $24.1 \%$. In the following years inflation declined, and during the weaker economic situation and crises in Asian countries, deflation occurred $(-0.8 \%$ in 1998 and $-1.4 \%$ in 1999). In the following years prices rose, but in 2002 deflation occurred again $(-0.8 \%)$. The good economic situation in the following years was accompanied by an increase in prices, which amounted to $5.9 \%$ in 2008 , but in 2009 prices fell by $0.7 \%$, to return to the growth path from 2010. High inflation occurred in 2011 (5.4\%), and then stabilized in the range of $1.4 \%-2.6 \%$. In general, price levels in China were characterised by high volatility, which shows that the central bank of China prioritised maintaining the exchange rate at the desired level, resulting in large fluctuations in price levels.

High inflation was observed in periods of high growth in exports and current account surpluses. China's exports fell during the global financial and economic

${ }^{5}$ Broad money is the sum of currency outside banks; demand deposits other than those of the central government; the time, savings, and foreign currency deposits of resident sectors other than the central government; bank and traveler's checks; and other securities such as certificates of deposit and commercial paper. 
crisis as external demand weakened, resulting in a decrease in the current account surplus and a decline in the price level. After the crisis, Chinese exports began to grow again, which was followed by foreign exchange reserves and inflation growth (chart 5 and chart 7). The stabilisation of the price level since 2012 coincided with a slowdown in the upward trend in foreign exchange reserves, and then with their decline, as well as a decline in the current account surplus since 2015.

The rise in prices has been a major challenge for economic policy in China, as inflation increases the real exchange rate, i.e. the real appreciation of the currency, which means a deterioration in the price competitiveness of exports. The analysis of the data presented in chart 8 shows that the periods of appreciation of the real effective exchange rate (REER) were accompanied by a decrease in the current account surplus, while the increase in the CA surplus occurred in the periods of depreciation of REER.

It should be noted that the export-led growth strategy pursued over the years, which included exchange rate policy, contributed on the one hand to China's high GDP growth, but its implementation was also a source of growing external and internal imbalances. In addition, this policy also had an impact on the global economy. The use of exchange rate policies as an instrument of export promotion contributed to an increase in the current account deficits in countries importing from China, and in particular the United States. Such a policy also affected the interests of some EU countries (Mucha-Leszko, 2018, pp. 167-169; Mucha-leszko \& Twarowska, 2016, pp. 34-35). As a result, the global payment imbalances were growing. Global payment imbalances are measured as the sum of the absolute value of world current account balances divided by world GDP (Kowalski \& Lesher, 2010, p. 129) (see chart 9).

Global payment imbalances increased in the 1990s from around 2\% of GDP to $3 \%$ in the early 2000 s, after which they started to grow very dynamically, reaching a peak of 5.5\% in 2006. The United States and China are the largest contributors to the creation of imbalances, but these countries are on the opposite sides, i.e. the USA has a permanent deficit, mainly in trade with China, and China has surpluses. China's share in the global payment imbalances has been increasing rapidly since the beginning of the 2000s, when it was around $2 \%$ and reached $12.5 \%$ in 2008 , and then, during the crisis, it started to decline and reached $4.7 \%$ in 2011. The financial and economic crisis has hindered the accumulation of global payment imbalances. The reduction of the imbalance was mainly due to cyclical factors, so that with the improvement of the global economic situation, the global imbalance increased again and China's share in the creation of the global payment imbalance increased to $11.1 \%$ in 2015, but in 2017 China's share dropped to 6.5\% (chart 10).

Global payment imbalances, which are largely the result of China's exchange rate policy, jeopardise the financial stability of the world economy and pose a risk of a global crisis. Moreover, the existence of chronic deficits and current account surpluses of systemically important countries is a sign of sub-optimal 
allocation of resources. This involves capital flows from developing countries to developed countries, resulting in developing countries' savings financing the deficits and consumption of developed countries.

\subsection{Evaluation of the renminbi as an international currency and prospects}

The significant costs to both the Chinese and global economy of China's strategy to support GDP growth by improving export competitiveness have led to changes in China's exchange rate policy. In addition, China's important position in the global economy has allowed it to aspire to become a country whose currency plays the role of an international currency. Influenced by the global financial and economic crisis (2008-2009), China has taken steps towards the internationalisation of the renminbi, which could lead to the evolution of the international monetary system towards a multipolar system. After an unsuccessful attempt to create a new world money based on SDR to replace the US dollar, the Chinese government opted for a strategy to increase the role of the renminbi as an international currency (Xiaochuan, 2009).

Since 2009 China has undertaken some concrete steps to push forward RMB internationalisation. Under the Renminbi trade settlement pilot scheme, which was launched on 6 July 2009, the ban on international trade transactions in renminbi was lifted (Cui, 2013, p. 68). In 2009, this involved only five cities, but since June 2010, the project has been extended to 20 provinces where around 95\% of all Chinese foreign trade companies were located. In 2011, almost all Chinese exporters and importers were allowed to issue invoices and settle foreign transactions in national currency. In addition, Chinese companies have been given the possibility to have renminbi accounts abroad and to freely allocate the funds collected there. The efforts that supported the internationalisation of the renminbi were also the implementation of RMB Qualified Foreign Institutional Investor, Dim Sum bonds, and bilateral currency swap agreements (Cui, 2013, p. 70).

The renminbi internationalisation process has also been accelerated by the opening of offshore markets for transactions in Chinese currency (RMBOffshore-Clearing-Hubs) first in Hong Kong and then in other financial centres (Topfer, 2018, p. 1053). In offshore centres there are clearing banks that enable payments in Chinese currency with entities in China and in other offshore centres, which increases the use of renminbi in international transactions. Moreover, at the end of 2015, China launched a system enabling easier settlement of cross-border transactions denominated in renminbi (The Cross-Border Interbank Payment System - CIPS), to which 19 banks were connected, including 8 foreign banks (CIPS, 2018). CIPS is an alternative to settlements with correspondent banks or clearing institutions from offshore centres, and by eliminating intermediaries, it allows to reduce transaction costs in foreign trade with China. 
As a result of the above mentioned actions and the growing position of China's economy, the use of renminbi in the international currency functions has increased. Renminbi has a particularly good chance of gaining an important position among international currencies in functions related to international trade (Twarowska, 2018, pp. 6056-6057). China's high share in international trade supports the use of renminbi in international payments. For several years renminbi kept its position as the fifth most active currency for domestic and international payments, with a share of $2.12 \%$ in August 2018. In terms of international payments only, the renminbi ranked eight with a share of $1.26 \%$ in August 2018 (chart 11).

On the foreign exchange market, the renminbi position is significantly improving. In 2001, the share of the Chinese currency was insignificant and it was ranked 35th among the currencies used on the currency market. In 2016, the renminbi was already ranked eighth with a share of $4 \%$ (table 3 ).

A factor that encouraged foreign entities to use the renminbi in international transactions was also the inclusion by the IMF of China's currency in the SDR basket. This meant that China's currency was recognised as an official reserve currency, which has a huge political and prestige significance for China. However, despite many reasons to keep foreign exchange reserves in the renminbi, it is still not a key reserve currency. Chinese currency accounted for 1.22\% of global foreign exchange reserves in 2017, and $1.84 \%$ at the end of the second quarter of 2018 (table 4). However, it is worth noting that central bank reserve managers are increasingly confident about the role of the renminbi as a reserve currency. As many as 29 reserve managers contributing to the survey expected the Chinese currency to account for 10-20\% of their portfolios by 2020 (ECB, 2017, p. 13).

A necessary condition for the renminbi to function as an international currency is the existence of a developed and open capital market in China (Mucha-Leszko \& Kąkol, 2009, p. 20). China has also made significant progress in this area. The process of opening up the capital market to foreign investors was initiated in July 2007 by allowing selected Chinese banks to issue bonds in Hong Kong in renminbi (dim-sum-bonds). The renminbi bonds were also issued by Hong Kong entities and foreign companies, which led to the creation of an offshore market for instruments denominated in the renminbi. Furthermore, in November 2014, the Shanghai Stock Exchange entered into cooperation with the Hong Kong Stock Exchange, which enabled foreign investors to acquire a limited number of Chinese shares listed in the renminbi and Chinese investors to purchase shares listed in Hong Kong. In February 2016, China opened its bond market, which is the world's third largest bond market for foreign investors after the United States and Japan (Furey et al., 2018, p. 3). Comparison of Access Channels to China Onshore Bond Market is presented in table 5.

The use of the renminbi as an international currency is supported in particular by the liberalisation of the financial market, including the creation of cross-bor- 
der Stock Connect platforms linking Chinese and foreign stock exchanges and the Cross-Border Interbank Bond Market (CIBM) as well as the introduction of Renminbi Qualified Institutional Investor Status, which has easy access to Chinese bond markets.

Generally, since early 2016, China has been on a deliberate policy path to open up its financial markets to overseas institutional investors. Quota-free access, currency convertibility, new hedging flexibility and Bond Connect are examples of some of these significant developments, which have provided favourable conditions for further internationalisation of the renminbi. Another opportunity for the growth of the use of the renminbi in the functions of the international currency may be the announcement, that in April 2019 Chinese bonds will begin joining the main global bond index, the Bloomberg Barclays Global Aggregate Index, meaning they will be widely held by international investors (Furey et al., 2018, p. 10).

\section{Conclusion}

China's exchange rate policy has been active and has for years remained one of the key elements of export-led growth strategy. Changing the growth model and reorienting it on domestic demand and consumption reduces the importance of exchange rate policy, which is becoming more passive. Moreover, in recent years, China has intensified its efforts to support the internationalisation of the renminbi, which should have a positive impact on the stability of global financial relations.

However, the renminbi is not yet in rivalry with the US dollar as the dominant international currency, although the Chinese currency's share as an international currency is increasing. China is becoming an increasingly open economy over the years and has become the world's largest economy in terms of GDP in PPP, as well as the world's largest exporter, but many factors limit the internationalisation of the renminbi. These barriers are mainly related to the weak development of China's financial market and the existence of obstacles to the capital flow. Moreover, the exchange rate system is also a barrier to further currency internationalisation. The introduction of a floating exchange rate regime for the renminbi can be expected to increase the use of China's currency as an international currency. An opportunity for further internationalisation of the renminbi has become the introduction of China's currency into the SDR basket, but in the coming years we should not expect significant changes in the hierarchy of international currencies and replacement of the dollar by another currency.

Further challenges for internationalisation of the renminbi are related to the policy pursued by the United States, and in particular to the increase in protectionism in trade policy. The threat of a trade war between China and the United States may contribute to slowing down reforms in China, which will have a negative impact on the internationalisation of the renminbi. 


\section{References}

BIS. (2016). Triennial central bank survey: global foreign exchange market turnover in April 2016. Retrieved 07.12.2018 from https://www.bis.org.

Calvo, G.A. (1999). Fixedversusflexible exchangerates: preliminaries of a turn-of-millennium rematch. Maryland: University of Maryland.

Calvo, G.A., \& Reinhart, C. (2002). Fear of floating. Quarterly Journal of Economics, 117(2). doi:10.1162/003355302753650274.

Cardoso, A., \& Duarte, A.P. (2017). The impact of the Chinese exchange policy on foreign trade with the European Union. Brazilian Journal of Political Economy, 37(4). doi:10.1590/0101-31572017v37n04al2.

Chen, X., \& Cheung, Y.-W. (2011). Renminbi going global. China \& World Economy, 19(2). doi:10.1111/j.1749-124X.2011.01232.x.

Cheung, Y.-W., Chinn, M.D., \& Fujii, E. (2007). The overvaluation of renminbi undervaluation. Journal of International Money and Finance, 26(5). doi:10.1016/j.jimonfin.2007.04.005.

Cheung, Y.-W., Ma, G., \& McCauley, R.N. (2011). Renminbising China's foreign assets. Pacific Economic Review, 16(2). doi:10.1111/j.1468-0106.2010.00531.x.

Cheung, Y-W., Hui, Ch-H., \& Tsang, A. (2016). Renminbi central parity: an empirical investigation. CESifo Working Paper, 5963.

Cheung, Y-W., Hui, Ch-H., \& Tsang, A. (2018). Renminbi central parity: an empirical investigation. Pacific Economic Review, 23(2). doi:10.1111/1468-0106.12267.

Chinn, M., \& Frankel, J.A. (2007). Will the euro eventually surpass the dollar as leading international reserve currency? In R.H. Clarida (Ed.). G7 current account imbalances: sustainability and adjustment. Chicago: University of Chicago Press.

CIPS. (2018). Phase 2 of RMB cross-border interbank payment system fully launched. Retrieved 27.11.2018 from http://www.cips.com.cn.

Cline, W.R. (2015). Estimates of fundamental equilibrium exchange rates. Peterson Institute for International Economics Policy Brief, PB 15(8).

COFER. (2018). Currency composition of official foreign exchange reserves. Retrieved 28.11.2018 from http://data.imf.org.

Cui, Y. (2013). The internationalization of the RMB: where does the RMB currently stand in the process of internationalization. Asia-Pacific Economic Literature, 27(2). doi:10.1111/apel.12045.

Drabek, Z., \& Brada, J.C. (1998). Exchange rate regimes and the stability of trade policy in transition economies. Journal of Comparative Economics, 26(4). doi:10.1006/jcec.1998.1557.

ECB. (2017). The international role of the euro: July 2017. Retrieved 17.12.2018 from https://www.ecb.europa.eu.

ECB. (2018). The international role of the euro: June 2018. Retrieved 17.12.2018 from https://www.ecb.europa.eu. 
Edwards, S. (2006). The relationship between exchange rates and inflation targeting revisited. NBER Working Paper Series, 12163. doi:10.3386/w12163.

Eichengreen, B. (2011). Exorbitant privilege: the rise and fall of the dollar. Oxford: Oxford University Press.

Eichengreen, B., \& Kawai, M. (Eds.). (2015). Renminbi internationalization: achievements, prospects, and challenges. Tokyo: Brookings Institution Press.

Frankel, J.A. (2006). On the yuan: the choice between adjustment under a fixed exchange rate and adjustment under a flexible rate. CESifo Economic Studies, 52(2). doi:10.1093/cesifo/ifl004.

Frankel, J.A. (2012). Internationalization of the RMB and historical precedents. Journal of Economic Integration, 27(3). doi:10.11130/jei.2012.27.3.329.

Frenkel, J.A. (1996). Recent exchange rate experience and proposals for reform. The American Economic Review, 86(2).

Funke, M., \& Gronwald, M. (2008). The undisclosed renminbi basket: are the marketstellingussomethingabout where therenminbi-US dollar exchange rate is going? World Economy, 31(12). doi:10.1111/j.1467-9701.2008.01141.x.

Funke, M., \& Rahn, J. (2005). Just how undervalued is the Chinese renminbi? The World Economy, 28(4). doi:10.1111/j.1467-9701.2005.00688.x.

Furey, D., Zhang, B., \& Binny, J. (2018). Opening of China's bond market: what global investors need to know. Retrieved 17.12.2018 from https://www.ssga. com.

Harrison, M., \& Xiao, G. (2018). Enhanced special drawing rights: how China could contribute to a reformed international monetary architecture. China e World Economy, 26(4). doi:10.1111/cwe.12248.

IMF. (2018). International financial statistics. Retrieved 28.11.2018 from http:// data.imf.org.

Korhonen, I., \& Ritola, M. (2011). Renminbi misaligned: results from meta-regressions. In Y.-W. Cheung, \& G. Ma (Eds.), Asia and China in the global economy. Singapore: World Scientific. doi:10.1142/9789814335270.

Kowalski, P., \& Lesher, M. (2010). A commercial policy package for rebalancing the global economy? In S. Claessens, S. Evenett, \& B. Hoekman (Eds.), Rebalancing the global economy: a primer for policymaking. London: CEPR.

Mucha-Leszko, B. (2018). Causes of the European Union's decreasing position in the global economy in 2000-2016. Problems of World Agriculture, 18(1). doi:10.22630/PRS.2018.18.1.15.

Mucha-Leszko, B., \& Kąkol, M. (2009). Will the financial economic crisis of 2008-2009 accelerate monetary integration in the EU? Eurolimes, 8.

Mucha-Leszko, B., \& Twarowska, K. (2016). The European Union as the global economic power. Comparative Economic Research, 19(3). doi:10.1515/ cer-2016-0019.

OECD. (2018). OECD statistic. Retrieved 28.11.2018 from https://stats.oecd. org. 
Pasierbiak, P. (2017). In the quest for dominance in East Asia: evolution of economic position of Japan and China. Research Papers of Wroctaw University of Economics, 486.

Prasad, E. (2016). The renminbi's ascendance in international finance. In R. Glick, \& M. Spiegel (Eds.), Policy challenges in a diverging global economy. San Francisco: Federal Reserve Bank of San Francisco.

Sachs, J.D. (1996). Economic transition and the exchange-rate regime. The American Economic Review, 86(2).

Schnatz, B. (2011). Global imbalances and the pretence of knowing FEERs. Pacific Economic Review, 16(5). doi:10.1111/j.1468-0106.2011.00567.x.

$\mathrm{Su}$, P., Jiang, X., \& Sun, W. (2018). The flexible acceleration mechanism of China's capital adjustment with the goal of consumption-driven sustainable growth. Sustainability, 10(3). doi:10.3390/sul0030886.

SWIFT. (2018). RMB tracker: monthly reporting and statistics on renminbi (RMB) progress towards becoming an international currency. Retrieved 28.11.2018 from https: / /www.swift.com.

Topfer, L-M. (2018). London's rise as an offshore RMB financial centre: state-finance relations and selective institutional adaptation. Regional Studies, 52(8). doi:10.1080/00343404.2016.1275538.

Twarowska, K. (2018). Analysis of the use of the Chinese renminbi as an international currency. In K.S. Soliman (Ed.), Proceedings of the 31st International Business Information Management Association Conference (IBIMA): innovation management and education excellence through vision 2020. Milan: International Business Information Management Association.

U.S. Department of the Treasury. (2018). Major foreign holders of treasury securities. Retrieved 17.12.2018 from http: / / ticdata.treasury.gov.

UNCTAD. (2018). UNCTAD statistic. Retrieved 28.11.2018 from http:/ / unctadstat.unctad.org.

Wickham, P. (1985). The choice of exchange rate regime in developing countries. IMF Economic Review, 32(2). doi:10.2307/3866841.

World Bank. (2018). World development indicators. Retrieved 28.11.2018 from https://data.worldbank.org.

Xiaochuan, Z. (2009). Reform the international monetary system: essay by Zhou Xiaochuan, Governor of the People's Bank of China. Retrieved 26.11.2018 from https://www.bis.org.

Zhang, M. (2012). Chinese stylized sterilization: the cost-sharing mechanism and financial repression. China \& World Economy, 20(2). doi:10.1111/j.1749-124X.2012.01279.x. 


\section{Acknowledgements}

Author contributions: author has given an approval to the final version of the article.

Funding: this research was undertaken as part of the Reasons for the growing importance of the renminbi as an international currency project and was fully funded by the Ministry of Science and Higher Education grant for young researchers in 2018.

Note: the results of this study were presented at 10th International Conference on Applied Economics Contemporary Issues in Economy (June 27-28, 2019, Torun, Poland). 


\section{Appendix}

Table 1.

Estimates of undervaluation and required appreciation of renminbi

\begin{tabular}{|c|c|c|c|c|c|}
\hline \multirow{2}{*}{ Authors/version } & \multirow{2}{*}{ Year } & \multicolumn{2}{|c|}{ Undervaluation (\%) } & \multicolumn{2}{|c|}{ Required appreciation (\%) } \\
\hline & & effective RER & USD & effective RER & USD \\
\hline \multicolumn{6}{|c|}{ PPP } \\
\hline Big Mac Index (2007); S & 2007 & - & -58 & - & 138 \\
\hline Bosworth (2004) & 2004 & - & -40 & - & 67 \\
\hline Cheung, Chinn and Fujii (2007); B-S & 2007 & - & -50 & - & 100 \\
\hline Coudert and Couharde (2005), B-S & 2003 & - & -33 to -29 & - & 41 to 50 \\
\hline Frankel (2004); B-S & 2000 & - & -36 & - & 56 \\
\hline Wang (2004); B-S & 2004 & -5 & - & 5 & - \\
\hline \multicolumn{6}{|c|}{ FEER } \\
\hline Anderson (2006) & 2006 & - & -20 to -15 & - & 18 to 25 \\
\hline Cline (2005) & 2005 & -17 & -31 & 21 & 45 \\
\hline Cline (2007) & 2007 & -15 to -10 & -28 to -25 & 11 to 18 & 34 to 39 \\
\hline Coudert and Couharde (2005) & 2003 & -23 & -35 to -31 & 30 & 44 to 54 \\
\hline Goldstein (2004) & 2004 & -30 to -15 & - & 18 to 43 & - \\
\hline Goldstein and Lardy (2006) & 2004 & -26 to -17 & - & 20 to 35 & - \\
\hline Goldstein and Lardy (2007) & 2007 & -38 to -26 & - & 35 to 60 & - \\
\hline Jeong and Mazier (2003) & 2000 & -33 & -38 & 49 & 60 \\
\hline Stolper and Fuentes (2007) & 2007 & - & -13 & - & 15 \\
\hline Wang (2004) & 2003 & -5 to 0 & - & 0 to 5 & - \\
\hline Wren-Lewis (2004) & 2003 & - & -18 to -16 & - & 19 to 22 \\
\hline \multicolumn{6}{|c|}{ BEER } \\
\hline Bénassy-Quéré et al. (2004) & 2001 & -14 & -31 to -29 & 16 & 41 to 44 \\
\hline Bénassy-Quéré (2006) & 2004 & -31 to -24 & -37 to -23 & 31 to 45 & 30 to 59 \\
\hline Coudert and Couharde (2005) & 2002 & - & -18 & - & 22 \\
\hline Funke and Rahn (2005) & 2002 & -6 to -3 & -11 & 3 to 6 & 12 \\
\hline MacDonald and Dias (2007) & 2007 & -30 to -7 & - & 8 to 42 & - \\
\hline Stolper and Fuentes (2007) & 2007 & - & -7 & - & 7 \\
\hline Wang (2004) & 2003 & 0 & - & 0 & - \\
\hline Wren-Lewis (2004) & 2002 & - & -18 to -16 & - & 19 to 22 \\
\hline
\end{tabular}

Note:

PPP — Purchasing Power Parity; FEER — Fundamental Equilibrium Exchange Rate; BEER — behavioral Equilibrium Exchange Rate; B-S — with Balassa-Samuelson effect; S - simple; RER — Real Exchange Rate.

The minus sign (-) indicates undervaluation. The estimates presented are not exhaustive and should only be indicative. For an undervaluation of $X \%$, the appreciation needed to achieve the balance value is $100[1 /(1-0.01 X)-1]$.

Source: Cardoso \& Duarte (2017, p. 875). 
Table 2.

Countries with the biggest foreign exchange reserves (shares in world reserves in \%)

\begin{tabular}{lllllrlr}
\hline & \multicolumn{2}{c}{2000} & & & \multicolumn{2}{c}{2006} \\
\hline Japan & 8.4 & Japan & 17.5 & China & 20.1 & China & 28.0 \\
Taiwan & 7.8 & China & 8.3 & Japan & 16.5 & Japan & 10.9 \\
US & 7.7 & Hong Kong & 5.3 & Russia & 5.6 & Saudi Arabia & 6.8 \\
Germany & 7.3 & Taiwan & 5.3 & Taiwan & 5.0 & Switzerland & 4.4 \\
Italy & 6.7 & Republic of Korea & 4.7 & Republic of Korea & 4.5 & Taiwan & 4.0 \\
Spain & 5.5 & Singapore & 3.9 & Saudi Arabia & 4.3 & Republic of Korea & 3.8 \\
France & 3.9 & Germany & 2.8 & India & 3.2 & Hong Kong & 3.5 \\
UK & 3.8 & US & 2.8 & Singapore & 2.6 & Brazil & 3.4 \\
China & 3.2 & UK & 2.3 & Hong Kong & 2.5 & India & 3.3 \\
Switzerland & 3.1 & India & 1.9 & Brazil & 1.6 & Russia & 3.2 \\
\hline
\end{tabular}

Source: Own preparation based on IMF (2018).

Table 3.

Currency distribution of OTC foreign exchange turnover (in \%)

\begin{tabular}{|c|c|c|c|c|c|c|c|c|c|c|c|c|}
\hline \multirow{2}{*}{ Currency } & \multicolumn{2}{|c|}{2001} & \multicolumn{2}{|c|}{2004} & \multicolumn{2}{|c|}{2007} & \multicolumn{2}{|c|}{2010} & \multicolumn{2}{|c|}{2013} & \multicolumn{2}{|c|}{2016} \\
\hline & Share & Rank & Share & Rank & Share & Rank & Share & Rank & Share & Rank & Share & Rank \\
\hline USD & 89.9 & 1 & 88.0 & 1 & 85.6 & 1 & 84.9 & 1 & 87.0 & 1 & 87.6 & 1 \\
\hline EUR & 37.9 & 2 & 37.4 & 2 & 37.0 & 2 & 39.1 & 2 & 33.4 & 2 & 31.3 & 2 \\
\hline JPY & 23.5 & 3 & 20.8 & 3 & 17.2 & 3 & 19.0 & 3 & 23.1 & 3 & 21.6 & 3 \\
\hline GBP & 13.0 & 4 & 16.5 & 4 & 14.9 & 4 & 12.9 & 4 & 11.8 & 4 & 12.8 & 4 \\
\hline AUD & 4.3 & 7 & 6.0 & 6 & 6.6 & 6 & 7.6 & 5 & 8.6 & 5 & 6.9 & 5 \\
\hline CAD & 4.5 & 6 & 4.2 & 7 & 4.3 & 7 & 5.3 & 7 & 4.6 & 7 & 5.1 & 6 \\
\hline $\mathrm{CHF}$ & 6.0 & 5 & 6.0 & 5 & 6.8 & 5 & 6.3 & 6 & 5.2 & 6 & 4.8 & 7 \\
\hline $\mathrm{CNY}$ & 0.0 & 35 & 0.1 & 29 & 0.5 & 20 & 0.9 & 17 & 2.2 & 9 & 4.0 & 8 \\
\hline SEK & 2.5 & 8 & 2.2 & 8 & 2.7 & 9 & 2.2 & 9 & 1.8 & 11 & 2.2 & 9 \\
\hline MXN & 0.8 & 14 & 1.1 & 12 & 1.3 & 12 & 1.3 & 14 & 2.5 & 8 & 2.2 & 10 \\
\hline
\end{tabular}

Source: Own preparation based on BIS (2016). 
Table 4.

Currency composition of official foreign reserves (in \%)

\begin{tabular}{lrrrrrrrrr}
\hline \multicolumn{1}{c}{ Shares of } & \multicolumn{1}{c}{1995} & 1999 & 2005 & \multicolumn{1}{c}{2011} & 2013 & 2015 & 2016 & 2017 & $2018 \mathrm{2} 2$ \\
\hline US dollars & 58.96 & 71.01 & 66.51 & 62.59 & 61.24 & 65.73 & 65.34 & 62.72 & 62.25 \\
euros & - & 17.90 & 23.89 & 24.40 & 24.20 & 19.13 & 19.13 & 20.15 & 20.26 \\
Japanese yen & 6.77 & 6.37 & 3.96 & 3.61 & 3.82 & 3.75 & 3.95 & 4.89 & 4.97 \\
pounds sterling & 2.11 & 2.89 & 3.75 & 3.83 & 3.98 & 4.71 & 4.34 & 4.54 & 4.48 \\
Canadian dollars & - & - & - & - & 1.83 & 1.77 & 1.94 & 2.02 & 1.91 \\
Chinese renminbi & - & - & - & - & - & - & 1.08 & 1.22 & 1.84 \\
Australian dollars & - & - & - & - & 1.82 & 1.77 & 1.69 & 1.80 & 1.70 \\
Swiss francs & 0.33 & 0.23 & 0.15 & 0.08 & 0.27 & 0.27 & 0.16 & 0.18 & 0.16 \\
Deutsche mark & 15.75 & - & - & - & - & - & - & - & - \\
ECUs & 8.53 & - & - & - & - & - & - & - & - \\
French francs & 2.35 & - & - & - & - & - & - & - & - \\
Netherlands guilders & 0.32 & - & - & - & - & - & - & - & - \\
other currencies & 4.87 & 1.60 & 1.74 & 5.49 & 2.84 & 2.86 & 2.37 & 2.49 & 2.44 \\
\hline
\end{tabular}

Source: Own preparation based on COFER (2018).

Table 5 .

\section{Comparison of Access Channels to China Onshore Bond Market}

\begin{tabular}{|c|c|c|c|c|c|c|c|}
\hline Date & Channel & Quota & $\begin{array}{l}\text { Quota size } \\
\text { (billions) }\end{array}$ & $\begin{array}{c}\text { Number } \\
\text { of investors }\end{array}$ & $\begin{array}{l}\text { Application } \\
\text { procedure }\end{array}$ & Timing & Restrictions \\
\hline 2002 & QFII & yes & USD 80 & c. 280 & $\begin{array}{l}\text { registration } \\
\& \mathrm{PBoC} \\
\text { approval }\end{array}$ & 12-18 months & lock-up period \\
\hline 2011 & RQFII & yes & $\begin{array}{l}\text { USD } 70 \\
\text { (CNY } \\
471)\end{array}$ & c. 180 & $\begin{array}{l}\text { registration } \\
\text { \& } \mathrm{PBoC} \\
\text { approval }\end{array}$ & 12-18 months & lock-up period \\
\hline 2016 & CIBM & no & unlimited & - & filing only & $\begin{array}{l}20 \text { days } \\
\text { acknowledgement, } \\
2 \text { months } \\
\text { to trading }\end{array}$ & $\begin{array}{l}\text { CNY in=CNY out } \\
(+/-10 \%)\end{array}$ \\
\hline 2017 & $\begin{array}{l}\text { bond } \\
\text { connect }\end{array}$ & no & unlimited & - & filing only & 2-4 weeks & $\begin{array}{l}\text { zero balance to be } \\
\text { maintained onshore; } \\
\text { surplus RMB will be } \\
\text { repatriated back to HK } \\
\text { automatically on a daily } \\
\text { basis }\end{array}$ \\
\hline
\end{tabular}

Source: Own preparation based on Furey et al. (2018, p. 8). 


\section{Chart 1.}

Official exchange rate in China in 1985-2017 (LCU per USD, period average)

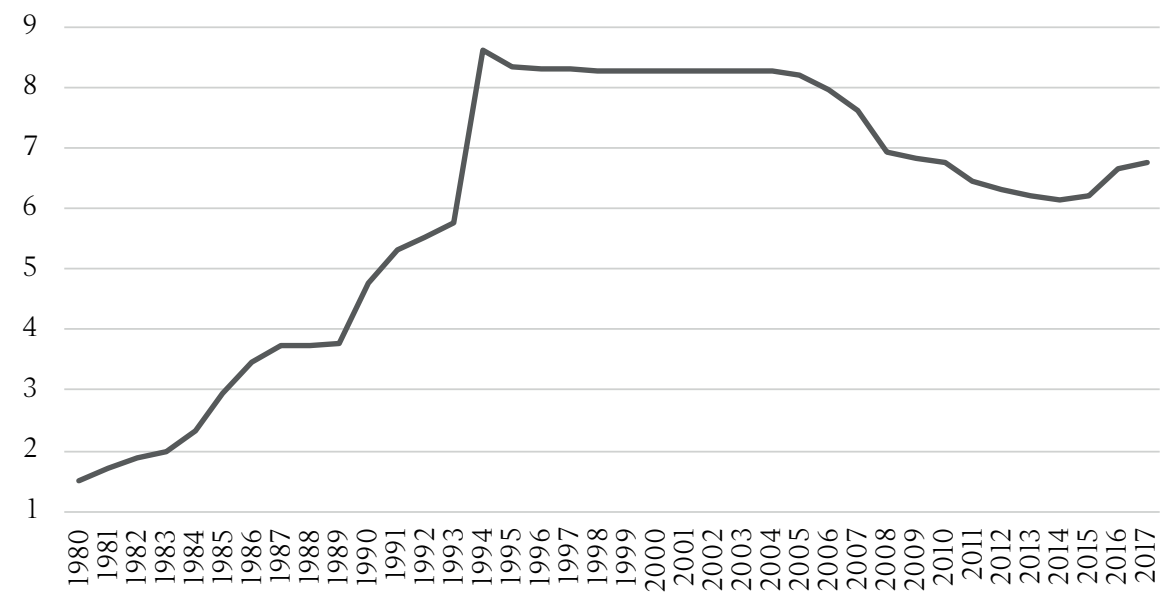

Source: Own preparation based on World Bank (2018).

Chart 2.

Real Effective Exchange Rate (CPI) in China in 1990-2017 (1990=100)

140

130

120

110

100

90

80

70

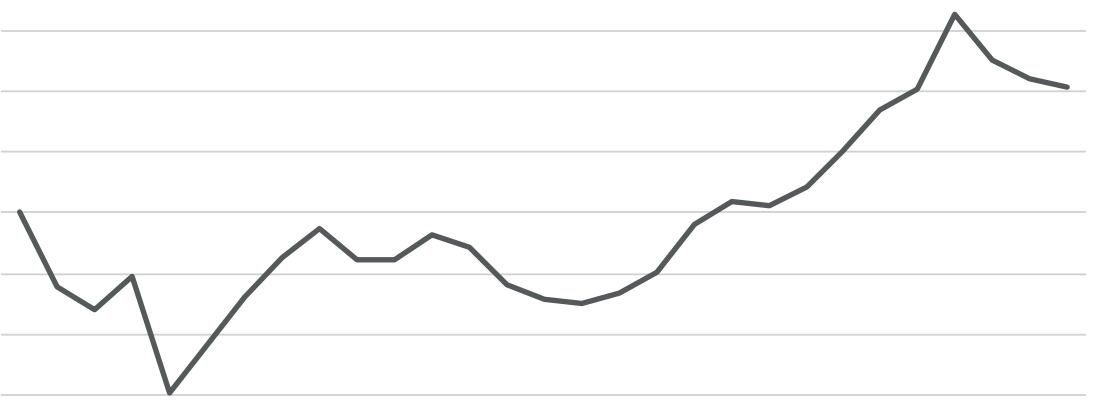

60

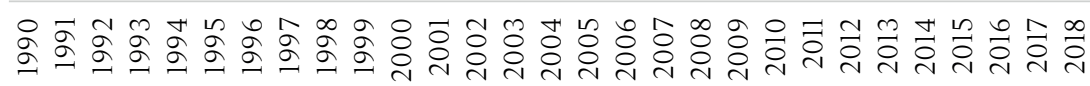

Source: Own preparation based on IMF (2018). 
Chart 3.

China's current account balance in 1982-2017 (in million USD on the left and in \% of GDP on the right)

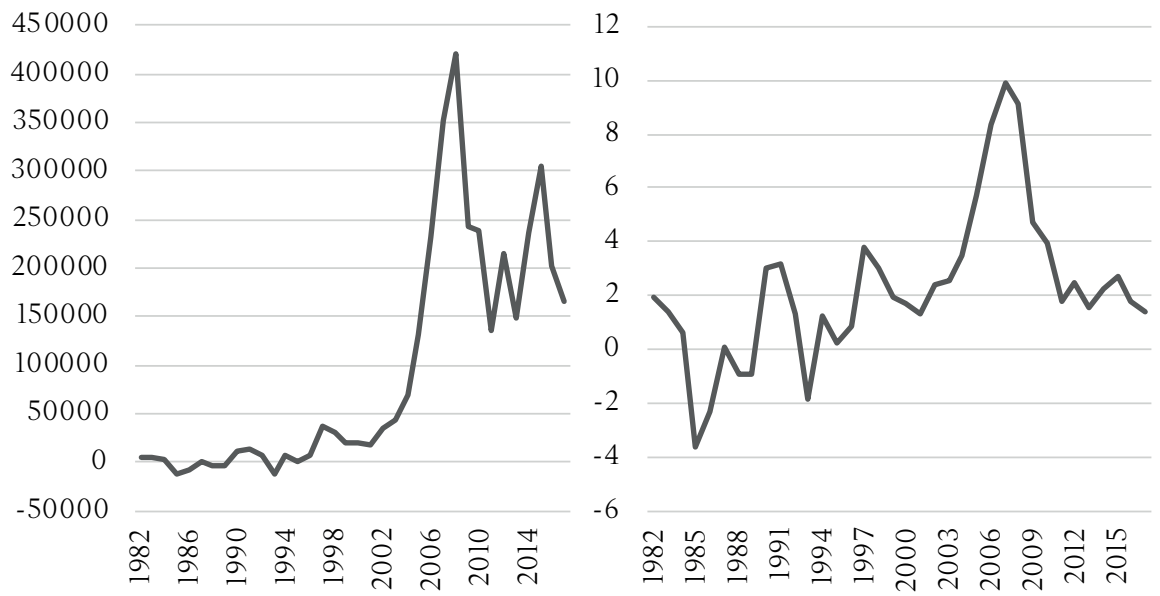

Source: Own preparation based on UNCTAD (2018).

\section{Chart 4.}

GDP growth (annual, in \%), current account balance (in \% of GDP) and official exchange rate in China (LCU per USD, period average) in 1985-2017

20

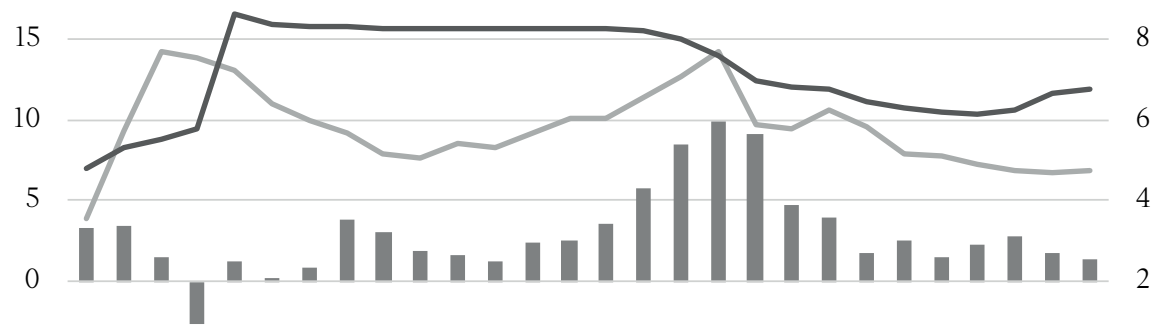

$-5$

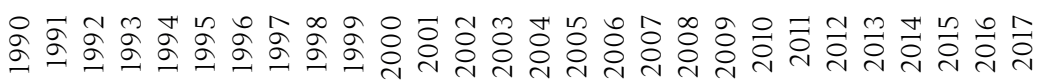

current account balance (left axis)

GDP growth (left axis)

_ official exchange rate (right axis)

Source: Own preparation based on World Bank (2018). 


\section{Chart 5.}

China's total reserves excluding Gold in 1990-2018 (in mln USD and in \% of world reserves)

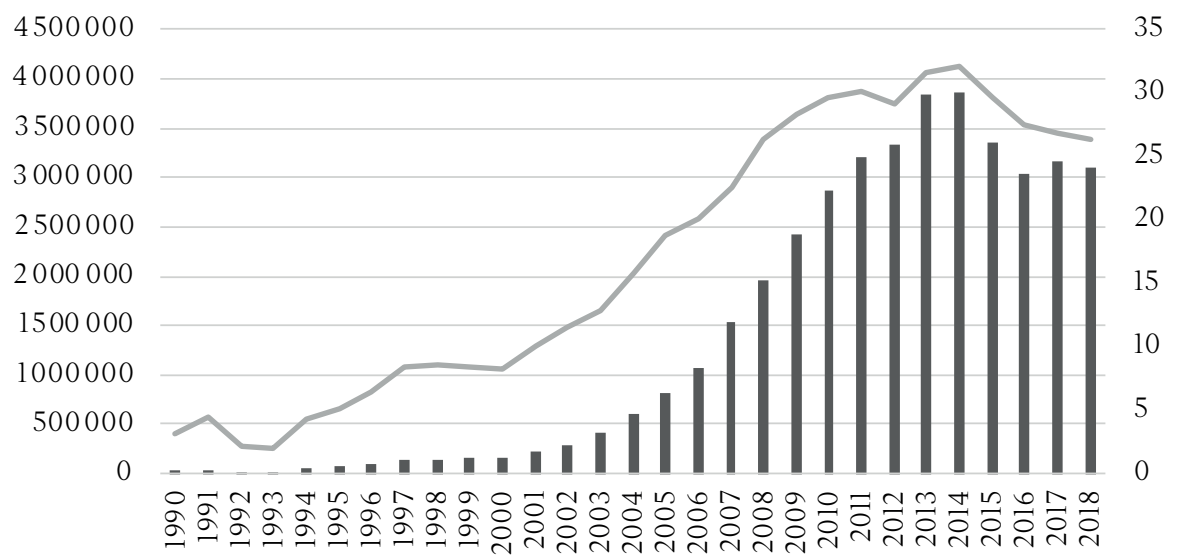

Source: Own preparation based on IMF (2018).

Chart 6.

Broad money in 1977-2017 (in \% of GDP)

250

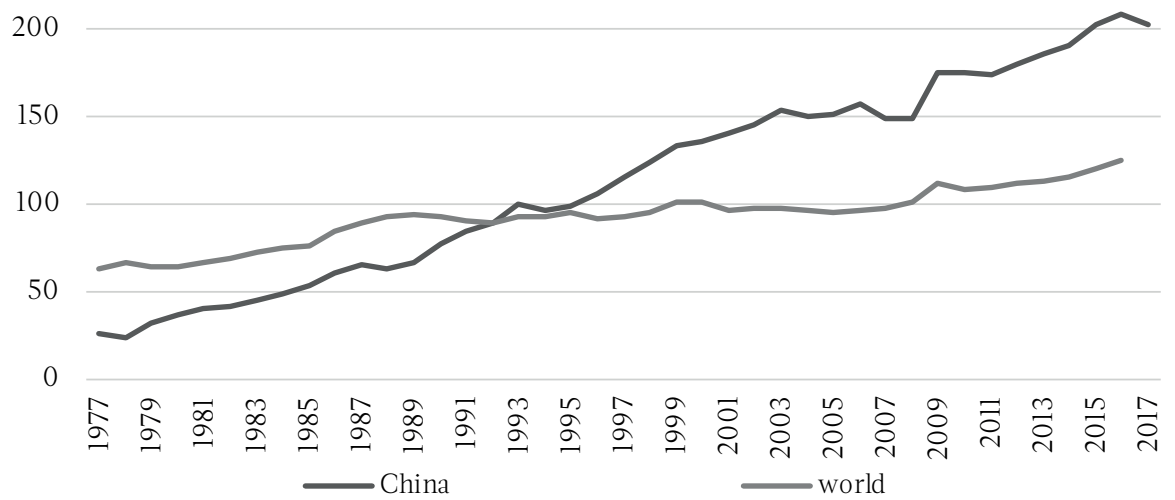

Source: Own preparation based on World Bank (2018). 
Chart 7.

Inflation CPI in China in 1985-2017 (percentage change on the same period of the previous year)

30

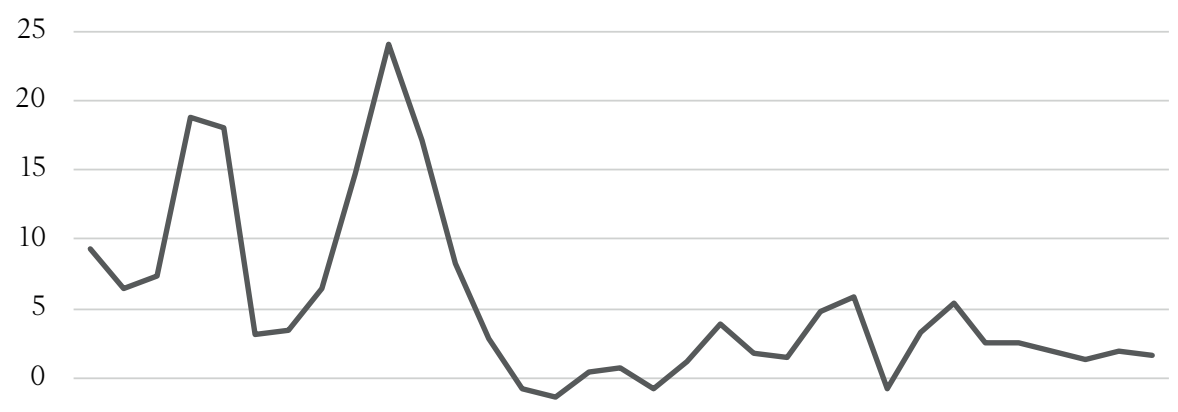

$-5$

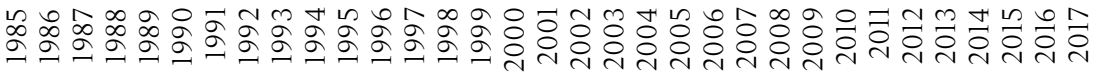

Source: Own preparation based on OECD (2018).

Chart 8.

Real Effective Exchange Rate (CPI, 1990=100) and balance of trade (in \% of GDP) in China in 1990-2017

140

130

120

110

100

90

80

70

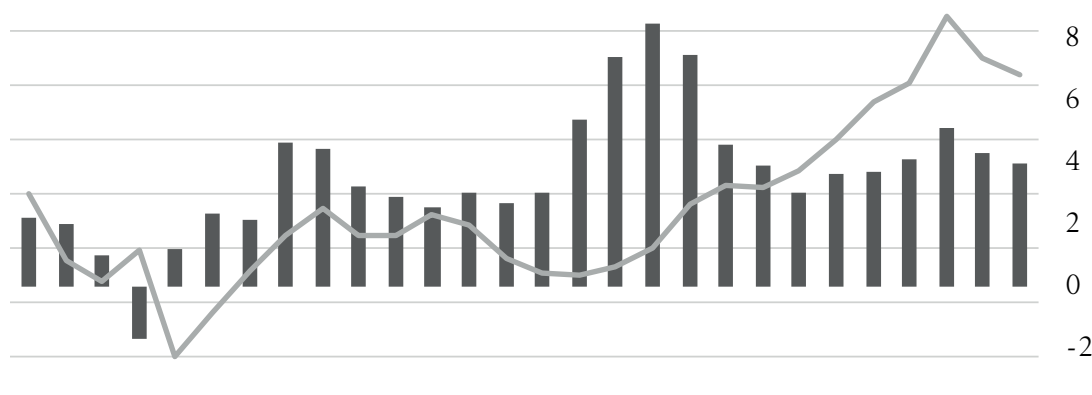

60

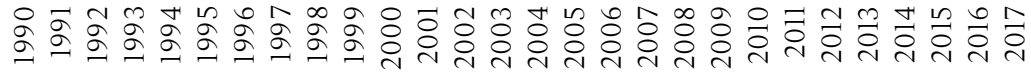

trade balance (right axis)

$\longrightarrow$ REER (left axis)

Source: Own preparation based on IMF (2018) and UNCTAD (2018). 


\section{Chart 9.}

Index of global payment imbalances in 1980-2017 (in \%)

6

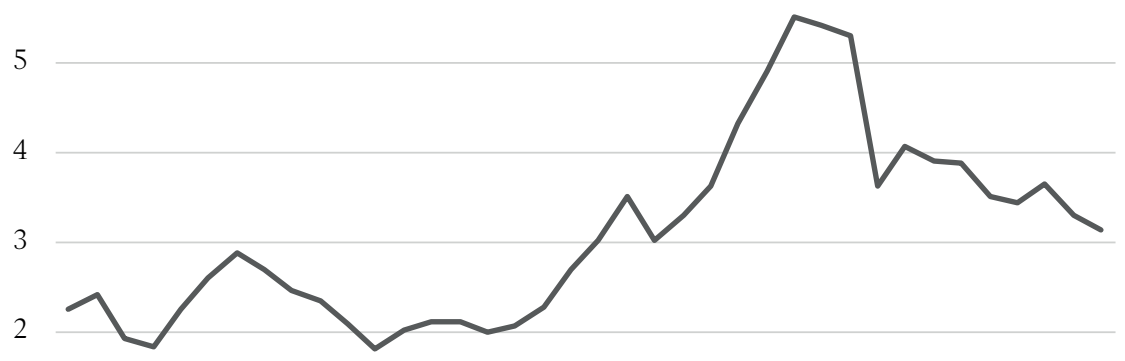

1

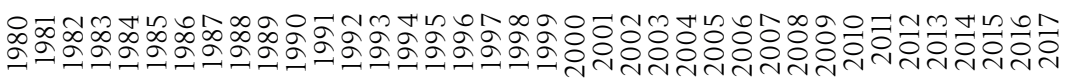

Note:

Sum of absolute values of current account deficit/surplus divided by world GDP

Source: Own preparation based on UNCTAD (2018).

Chart 10.

Shares of China and the USA in accumulated global payment imbalances (current account deficit/surplus; US Dollars at current prices in millions)

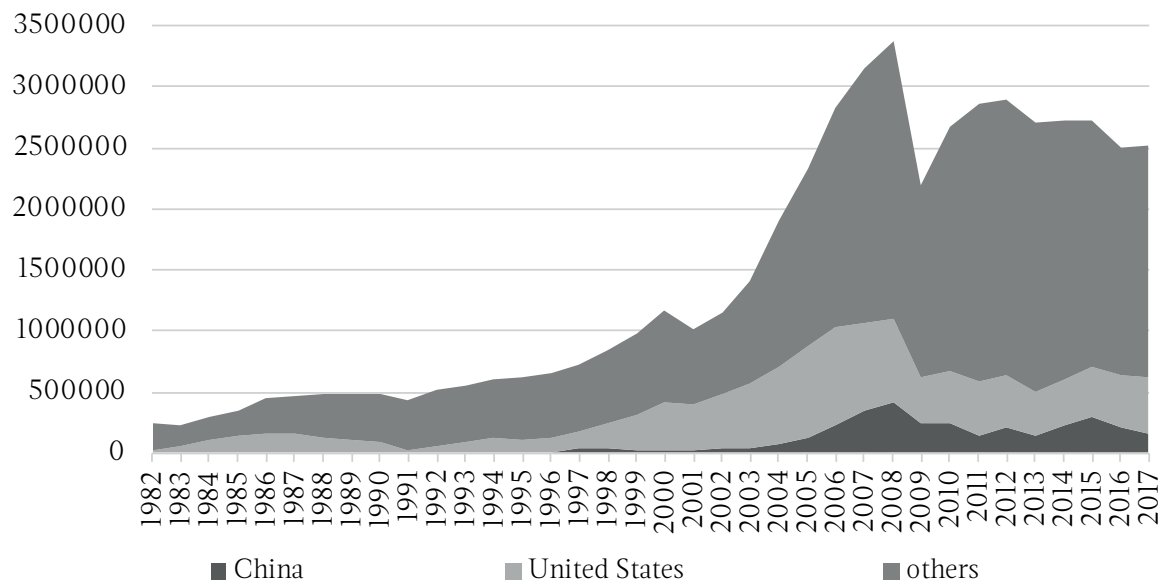

Note:

Sum of absolute values of current account deficit/surplus divided by world GDP

Source: Own preparation based on UNCTAD (2018). 


\section{Chart 11.}

Currencies' shares in domestic and international payments (on the left) and in international payments (on the right) in August 2018 (in \%)

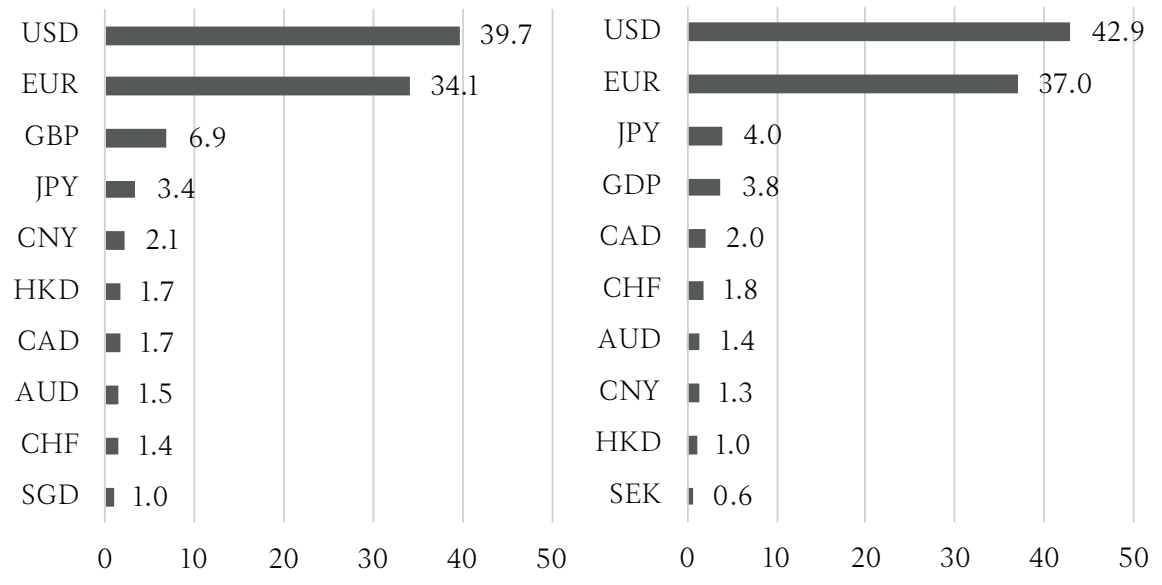

Source: Own preparation based on SWIFT (2018, pp. 3-4). 